\title{
Thermal modification of microstructures and grain boundaries in silicon carbide
}

\author{
Xiao Feng Zhang ${ }^{1}$, and Lutgard C. De Jonghe ${ }^{1,2}$ \\ ${ }^{1}$ Materials Sciences Division, Lawrence Berkeley National Laboratory \\ University of California, Berkeley, CA 94720 \\ ${ }^{2}$ Department of Materials Science and Mineral Engineering \\ University of California, Berkeley, CA 94720
}

\begin{abstract}
Polycrystalline SiC samples hot-pressed with aluminum, boron, and carbon sintering additions (ABC-SiC) were characterized using transmission electron microscopy. The study focused on the effects of high temperature treatment on microstructure. Three temperatures were found critical at which considerable microstructural changes took place. At a threshold temperature of $\sim 1000^{\circ} \mathrm{C}, 1 \mathrm{~nm}$-wide, amorphous intergranular films started to crystallize. At $\sim 1300^{\circ} \mathrm{C}$, lattice diffusion in $\mathrm{SiC}$ grains resulted in nanoprecipits which could diffuse into grain boundaries and significantly altered composition there. Quantitative microanalysis revealed doubled $\mathrm{Al}$ content in intergranular films after annealing at $1300^{\circ} \mathrm{C}$. Except crystallization in intergranular films and nano-precipitation in matrix grains, microstructure remained stable until $1600^{\circ} \mathrm{C}$, at which microstructural changes with volatile features. A brief holding at $1900^{\circ} \mathrm{C}$ brought marked changes in microstructure, including structural change in intergranular films, dissolved nanoprecipitates, unit cell dilation, and cracking. The results indicate that $\mathrm{ABC}-\mathrm{SiC}$ is highly promising in structural applications at up to $1500^{\circ} \mathrm{C}$.
\end{abstract}

Keywords: Ceramic, Annealing, Microstructure, Grain boundaries, TEM. 


\section{INTRODUCTION}

SiC possesses many attractive properties such as low density and thermal expansion coefficient, good in thermal conductivity, hardness, elastic modules, flexural strength, and thermal shock resistance. However, the use of SiC to date has been limited by its low fracture toughness $\left(K_{I c}, \sim 2-5 \mathrm{MPa}^{1 / 2}\right.$ for commercially available materials). Various attempts have been made to improve toughness, including reinforcement with aluminacoated SiC platelets, ${ }^{1}$ and in situ toughening. The in situ toughening mechanism, which was effective for $\mathrm{Si}_{3} \mathrm{~N}_{4}$ ceramics, ${ }^{2,3}$ also led to significantly enhanced toughness for $\mathrm{SiC}^{4} \mathrm{~A}$ microstructure containing elongated, plate-like $\mathrm{SiC}$ grains was produced by hot pressing mixture of $\alpha-\mathrm{SiC}$ with $\mathrm{Al}_{2} \mathrm{O}_{3}$ and $\mathrm{Y}_{2} \mathrm{O}_{3},{ }^{5}$ while $\beta$-SiC hot-pressed with aluminum, boron, and carbon additives (ABC-SiC) led to further enhancement of the fracture toughness. ${ }^{4}$ In the latter, liquid phases were formed at processing temperatures, leading to the formation of residual intergranular films (IGFs). ${ }^{4,6-11}$ The nature of these amorphous intergranular films was shown to consist mainly of $\mathrm{Al}-\mathrm{O}-\mathrm{Si}-\mathrm{C}^{11}$ or $\mathrm{Al}-\mathrm{O}-\mathrm{C},{ }^{12,13}$ and to provide a path for intergranular crack propagation. Elastic bridging and pullout of the interlocked SiC grains $^{4,5,14}$ contributed to the toughening, ${ }^{2,15-17}$ leading to fracture toughness of as high as 9 $\mathrm{MPa} . \mathrm{m}^{1 / 2}$ for $\mathrm{ABC}-\mathrm{SiC} .^{4}$

In general, it can be expected that glassy grain-boundary films in ceramic materials benefit room temperature toughness but degrade high temperature properties due to their softening. However, extensive mechanical studies demonstrated positive responses of $\mathrm{ABC}-\mathrm{SiC}$ to high temperature exposure. ${ }^{18-25}$ This enhancement in mechanical performance is likely a consequence of structural and chemical modifications that result from the heat treatments. In this paper, we report on the effects of the thermal treatment on microstructure of ABC-SiC.

\section{EXPERIMENTAL}

\section{Materials Processing}

Submicron $\beta$-SiC (B20, H. C. Starck, Germany) powder was mixed with $3 \mathrm{wt} \%$ aluminum (H-3 and H-10, Valimet, Stockton, CA), 0.6 wt\% boron (Callery Chemical Co, Callery, PA), and 2 wt $\%$ carbon sintering additives. Apiezon wax (AVO Biddle Instruments, Blue Bell, PA) was dissolved in toluene to serve as the carbon source, and then 
$\mathrm{Al}, \mathrm{B}$, and $\beta$-SiC powders were added. The slurry was ultrasonically agitated, stir dried, sieved through a 200 mesh screen, and uniaxially pressed at $35 \mathrm{MPa}$. Hot-pressing was conducted in an argon atmosphere at $1900^{\circ} \mathrm{C}$, at $50 \mathrm{MPa}$, for 1 hour. $38 \mathrm{~mm}$ diameter and $4 \mathrm{~mm}$ thick disks were produced, containing polycrystalline $\mathrm{SiC}$ dominated by $\alpha-4 \mathrm{H}$ and $\alpha-6 \mathrm{H}$ phases. The samples were referred to as ABC-SiC. High density $(>99 \%)$, high bend strength (typically a $660 \mathrm{MPa} \mathrm{MOR}$ ) and a reproducible fracture toughness of 5 to 7 MPa.m ${ }^{1 / 2}$ were achieved without further post-treatment.

\section{Thermal Treatment}

The as-hot-pressed $\mathrm{ABC}-\mathrm{SiC}$ samples were heat-treated in a tungsten mesh furnace under flowing Ar, at temperatures ranging between 800 to $1600^{\circ} \mathrm{C}$, for 5 to $840 \mathrm{hrs}$. Heating rates to $800^{\circ} \mathrm{C}$ were $10^{\circ} \mathrm{C} / \mathrm{min}$, and $4^{\circ} \mathrm{C} / \mathrm{min}$ to any higher temperatures. One of the samples was first annealed at $1500^{\circ} \mathrm{C}$ for $168 \mathrm{hrs}$ and cooled to room temperature, followed by a brief reheating to $1900^{\circ} \mathrm{C}$ with a 5 min dwell. All samples were examined using transmission electron microscopy (TEM).

\section{TEM Characterization}

$3 \mathrm{~mm}$ disks were cut from the $\mathrm{SiC}$ bulks, perpendicular to the hot pressing direction, mechanically ground and polished, dimpled, and thinned to electron transparency by Ar ion beam milling. The areas to be investigated by TEM were further than $100 \mathrm{~m}$ from the surface of the hot-pressed samples. One exception was for the SiC sample annealed at $1900^{\circ} \mathrm{C}$. In this case, the near-surface features were of particular interest, since evaporation

of some material could lead to additional structural and chemical changes. ${ }^{26}$ Therefore, after the $1900^{\circ} \mathrm{C}$ treatment, TEM samples were prepared by thinning only from one side to allow examination of the near-surface region.

The structural and chemical characterizations were carried out in a Philips CM200 field-emission gun transmission electron microscope operating at $200 \mathrm{kV}$. For compositional determinations, a 3.5 to $10 \mathrm{~nm}$ probe, a windowless detector with an X-ray energy-dispersive spectroscopy (EDS) system, and ES Vision 4.0 software issued by EMISPEC System, Inc. were used. The methodology for quantifying compositions of the nanometer-wide $\mathrm{SiC}$ grain boundary films have been described in detail previously. ${ }^{11-27}$ 


\section{RESULTS}

\section{Thermal Treatments at 800 to $1600^{\circ} \mathrm{C}$}

Fig. 1 shows the general microstructure of the as-hot-pressed ABC-SiC. $\alpha-S i C$ grains, with a width of 1 to $3 \mu \mathrm{m}$, and an aspect ratio between 2 and 5, constitute about 90 $\%$ of the elongated $\mathrm{SiC}$ grains. Equiaxed $\beta-\mathrm{SiC}$ grains were also present, with a size generally below $1 \mu \mathrm{m}$. Amorphous IGFs were prevalent with a typical width of about 1 nm. ${ }^{11}$ EDS microanalyses by Zhang et al. determined that the majority of the amorphous IGFs contained Al-O-Si-C constituents. ${ }^{11,27}$ The oxygen in IGFs came most likely from oxide surface layers on the $\mathrm{SiC}$ starting powder. As a rough estimate, formation of $1 \mathrm{~nm}$ wide $\mathrm{Al}-\mathrm{O}-\mathrm{Si}-\mathrm{C}$ grain boundary films in the sintered $\mathrm{SiC}$ could result from a $0.1 \mathrm{~nm}$ thick $\mathrm{SiO}_{2}$ surface layer on the starting powder. While the $\mathrm{SiO}_{2}$ thickness on as-received $\mathrm{SiC}$ powder is typically on the order of $5 \mathrm{~nm},{ }^{28}$ there is sufficient oxygen to form not only the IGFs but also various oxygen-rich secondary phases. ${ }^{29}$

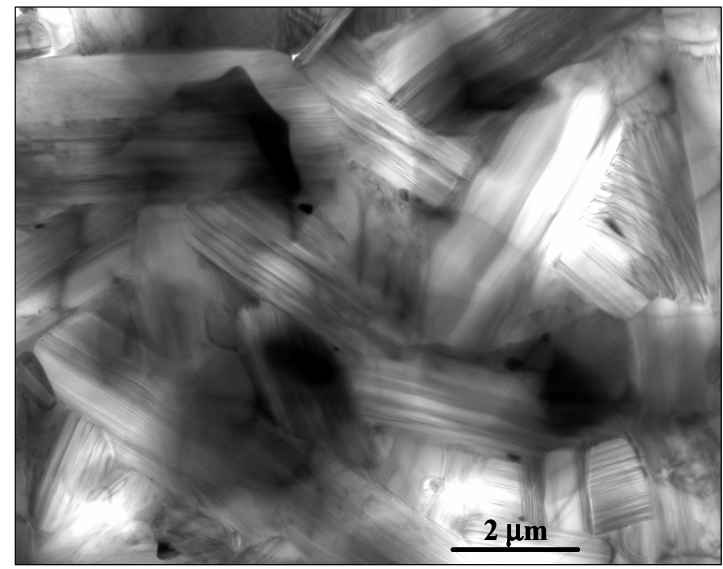

Fig. 1: General microstructural morphology of as-hot-pressed ABC-SiC.

Annealing at 800 to $1000^{\circ} \mathrm{C}$ did not lead to discernable microstructural changes. However, when subjected to post-annealing at or above $1000^{\circ} \mathrm{C}$, the amorphous IGFs started to crystallize. Fig. 2 shows high-resolution images for three different IGFs in a sample annealed at $1000^{\circ} \mathrm{C}$ for 5 hrs. An amorphous IGF is seen in Fig. 2a and a fully ordered IGF in Fig. 2c. Fig. 2b shows a partially ordered IGF structure. The range of IGF structures in Fig. 2 indicated that the crystallization of the amorphous IGFs was initiated at 
about $1000^{\circ} \mathrm{C}$ Holding the samples at $1000^{\circ} \mathrm{C}$ for $5-30 \mathrm{hrs}$ transformed about half number of the amorphous IGFs into more ordered structures. Annealing at higher temperatures for prolonged times crystallized the IGFs fully, as reported earlier, as an aluminosilicate with a 2H-wurtzite structure. ${ }^{11}$
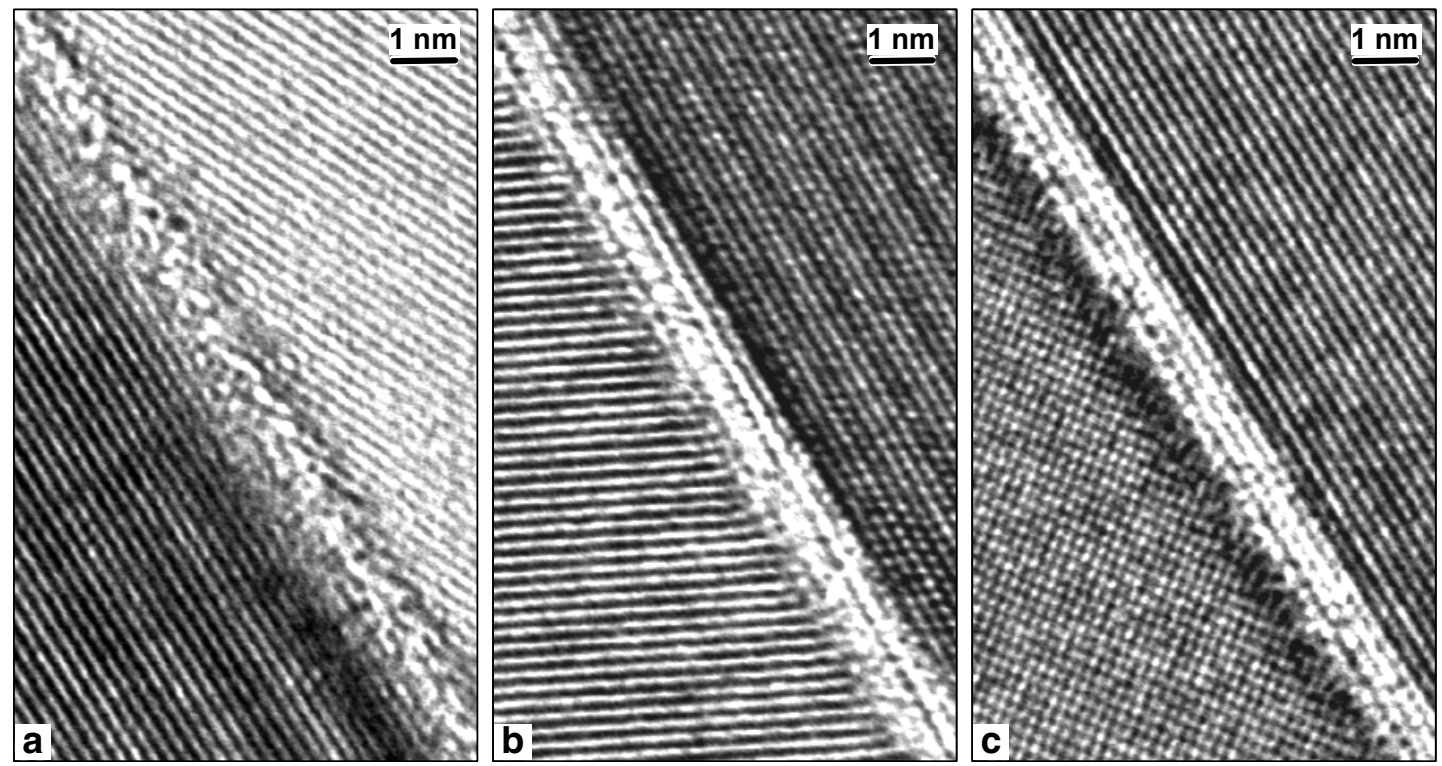

Fig. 2: Three high-resolution images taken from an ABC-SiC sample annealed at $1000^{\circ} \mathrm{C}$ for 5 hrs. IGFs with (a) amorphous, (b) partially ordered, and (c) crystallized structures can be seen.

To confirm the IGF crystallization process at elevated temperatures, an ABC-SiC sample was heated in-situ, in a $300 \mathrm{kV}$ JEOL 3010 transmission electron microscope equipped with a hot stage. Fig. 3 shows high-resolution images for the same IGF area before and after in-situ heating. The amorphous IGF prior to heating, Fig. 3a, shows localized crystallization after $25 \mathrm{hrs}$ at $1200^{\circ} \mathrm{C}$, Fig. $3 \mathrm{~b}$. The crystallization tended to proceed epitaxially on the (0001) plane of the adjacent $6 \mathrm{H}-\mathrm{SiC}$ matrix grain, with a $2 \mathrm{H}-$ wurtzite structure similar to that found in furnace-annealed $\mathrm{SiC}$ samples. No discernable features could be identified as potential preferential sites for nucleation at the $\mathrm{SiC} / \mathrm{IGF}$ interface. Presumably, local compositional fluctuations in the IGF serve as nucleation sites. 

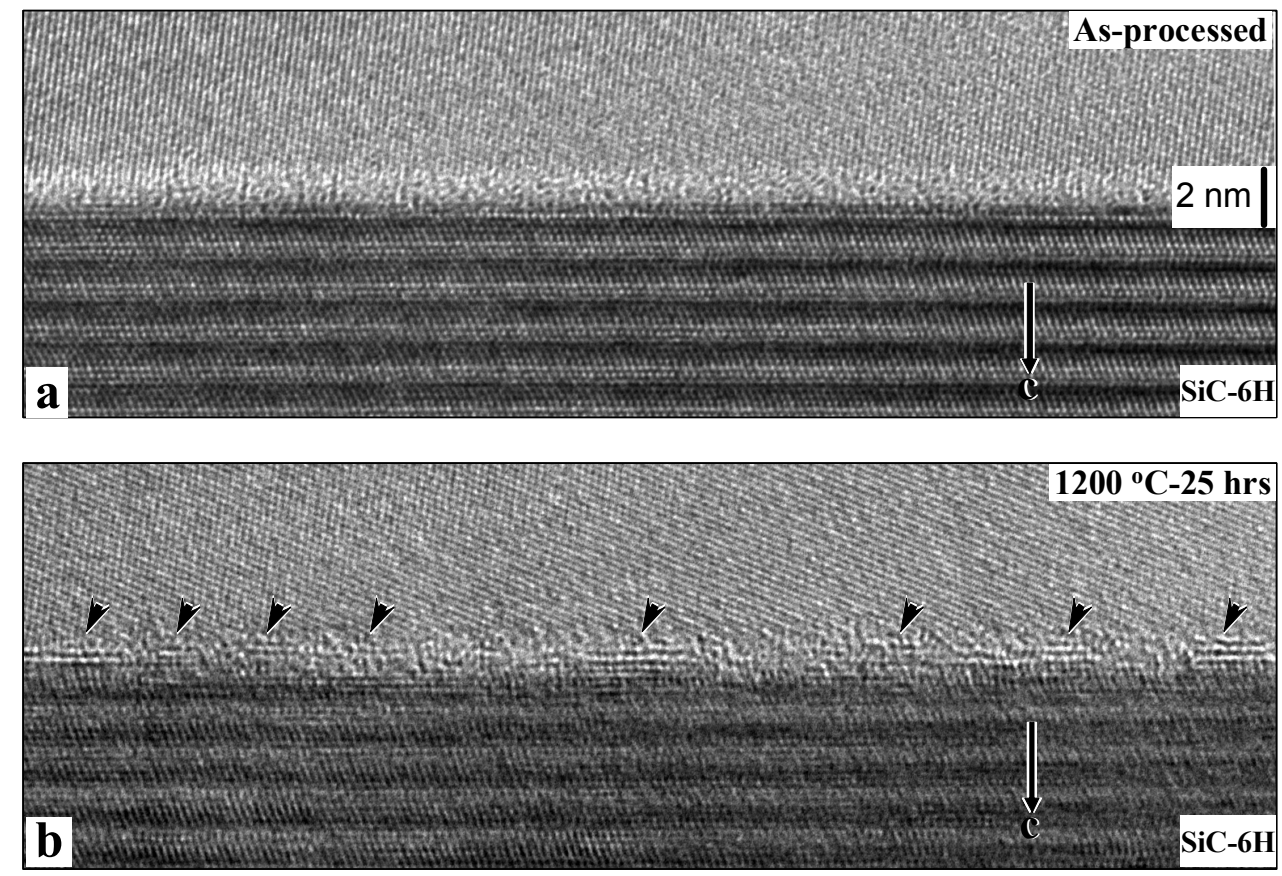

Fig. 3: (a), High-resolution image of an amorphous IGF in as-hot-pressed ABC-SiC. (b), The same IGF area as in (a) but after in-situ heating in a transmission electron microscope at $1200^{\circ} \mathrm{C}$ for $25 \mathrm{hrs}$. Arrows indicate the discrete, crystallized IGF segments. The high-resolution image in (b) was taken at room temperature.

Another significant consequence of the thermal treatment was nano-precipitation within $\mathrm{SiC}$ matrix grains, as seen in Fig. 4. Although Fig. 4 was taken from a sample annealed at $1400^{\circ} \mathrm{C}$, the plate-like nanoprecipitates already formed at $1300^{\circ} \mathrm{C}$. The projected dimension of the precipitates after $1300^{\circ} \mathrm{C}$ annealing is $\sim 4 \times 1 \mathrm{~nm}^{2}$ with a volumetric number density of $5 \times 10^{22} / \mathrm{m}^{3}$. The precipitates coarsened with annealing temperature, accompanied by decrease in the number density. Detailed high-resolution electron microscopy characterization and nano-probe EDS analysis determined an $\mathrm{Al}_{4} \mathrm{C}_{3}$ based structure and composition with $\mathrm{Si}$ and $\mathrm{B}$ solutions for the nanoprecipitates. The formation of the precipitates was a consequence of diffusion-controlled classic nucleation and growth. ${ }^{21,23}$ Direct evidence for $\mathrm{Al}$ lattice diffusion trough the $\mathrm{SiC}$ was the formation of precipitate-depletion zones along the grain boundaries, Fig. 4. The precipitate-depletion zones broadened with increasing annealing temperature, allowing an estimate of $\mathrm{Al}$ transport rates through $\mathrm{SiC}$ grains: $\sim 10^{-17} \mathrm{~cm}^{2} / \mathrm{sec}$ at $1400^{\circ} \mathrm{C}$. 


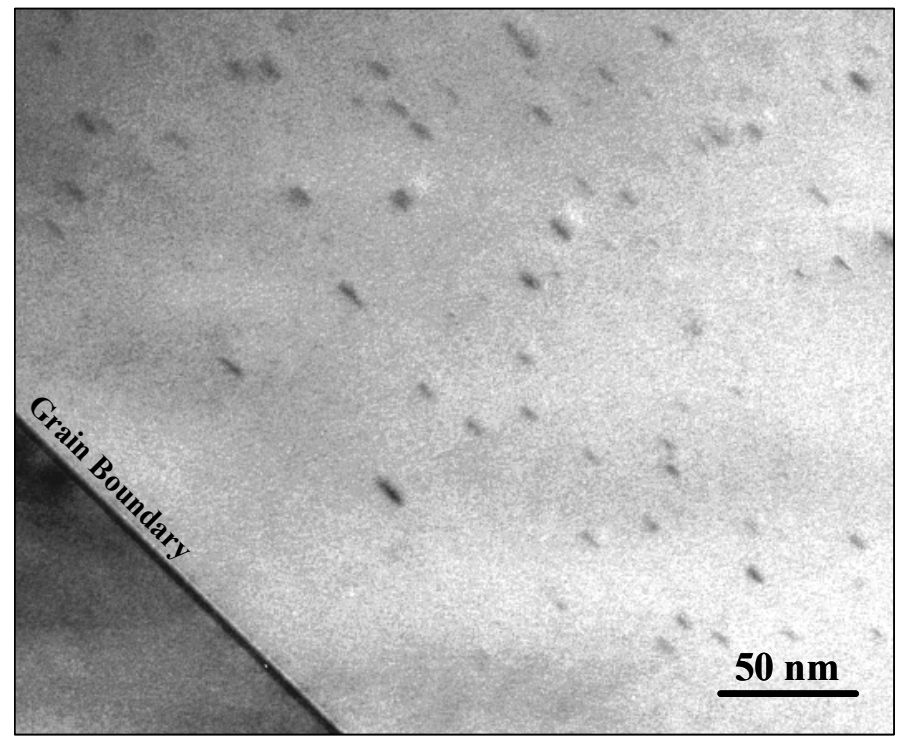

Fig. 4: Nanoprecipitates formed in an $\mathrm{ABC}-\mathrm{SiC}$ sample annealed at $1400^{\circ} \mathrm{C}$. Precipitate-depletion zone along the grain boundary can be seen.

The diffusion of the solutes in SiC lattice changed the grain boundary composition. Since boron is too light to be accurately quantified by EDS, and $\mathrm{Si}$ and $\mathrm{C}$ signals are inevitably interfered with signals from adjacent $\mathrm{SiC}$ grains, the systematic change of the $\mathrm{Al}$ content in IGFs as a function of annealing temperature was analyzed with EDS. The results are plotted in Fig. 5, in which one can notice that Al solution in $\mathrm{SiC}$ grains decreased at $1100^{\circ} \mathrm{C}$ and especially at above $1300^{\circ} \mathrm{C}$, consistent with TEM observations that Al solutions exsolved from $\mathrm{SiC}$ lattice to form nanoprecipitates. Not surprisingly, the Al site density in the grain boundaries $\left(\mathrm{N}_{\mathrm{Al}}{ }^{\mathrm{GB}}\right)$ changed as well upon annealing. Despite the large standard deviations, some conclusions can still be drawn. For example, $\mathrm{N}_{\mathrm{Al}}{ }^{\mathrm{GB}}$ for the samples annealed at $1000-1200{ }^{\circ} \mathrm{C}$ remained essentially unchanged. It can be derived that the composition of IGFs was invariant between $1000^{\circ} \mathrm{C}$ and $1200^{\circ} \mathrm{C}$, while the IGF crystallized. The $\mathrm{N}_{\mathrm{Al}}{ }^{\mathrm{GB}}$ value was doubled at $1300^{\circ} \mathrm{C}$, accompanied by a $20-45 \%$ decrease of the grain boundary width. This $\mathrm{Al}$ site density is in agreement with $\mathrm{Al}_{1.1} \mathrm{Si}_{0.9} \mathrm{OC}$, a solid solution between $2 \mathrm{H}$-wurtzite $\mathrm{Al}_{2} \mathrm{OC}$ and $\mathrm{SiC}^{30}$ At even higher annealing temperatures up to $1600^{\circ} \mathrm{C}$, both $\mathrm{N}_{\mathrm{Al}}^{\mathrm{GB}}$ and the grain boundary width changed marginally, taking the standard deviation into account. The decrease in grain boundary width can be understood in part as a volume contraction of the IGFs due to amorphous-to-crystalline transformation, and exsolution of SiC onto the adjacent grain surfaces. The significant increase in $\mathrm{Al}$ 
content in IGFs at $1300^{\circ} \mathrm{C}$ can be readily correlated with diffusion of the Al-rich chemical species into the grain boundary films (Fig. 4). At higher than $1300^{\circ} \mathrm{C}$, the $\mathrm{Al}$ content in IGFs became more or less saturated.

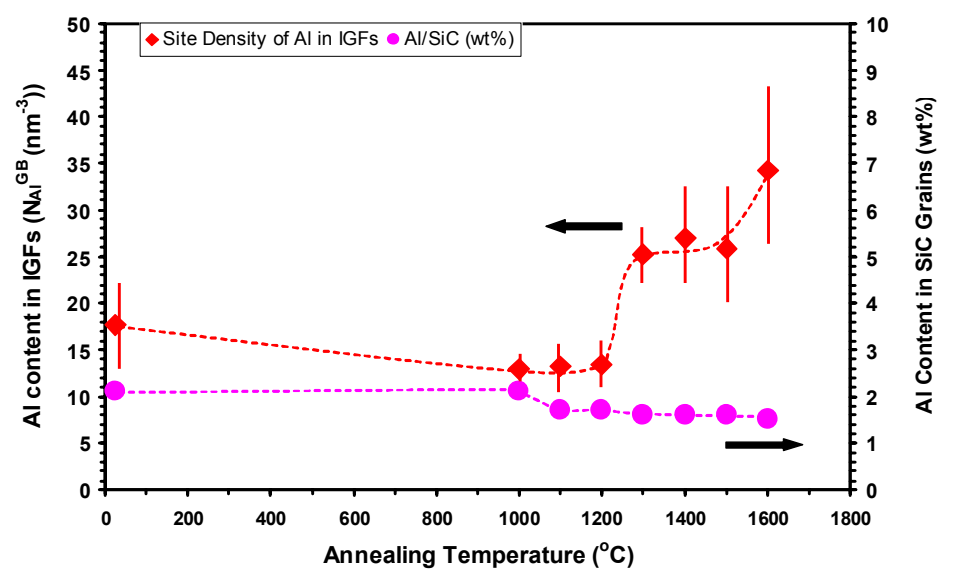

Fig. 5: Plots of EDS-determined $\mathrm{Al}$ site density in grain boundary films $\left(\mathrm{N}_{\mathrm{Al}}{ }^{\mathrm{GB}}\right)$ and in $\mathrm{SiC}$ matrix grains $(\mathrm{Al} / \mathrm{SiC}, \mathrm{wt} \%)$ as a function of annealing temperature. Standard deviations are given.

In addition to microstructural and compositional changes in the intergranular films, annealing at $1400^{\circ} \mathrm{C}$ or above for a prolonged time also resulted in local dissolution of $\mathrm{SiC}$ grains and secondary phases, as evidenced by SiC grains with faceted edges as well as triple-junction particles with round corners. Further phase separation also occurred within some secondary phase particles, as shown in Fig. 6. Secondary phase particles became volatile at $1600^{\circ} \mathrm{C}$, leaving a large number of empty triple-pockets, Fig. 7. 


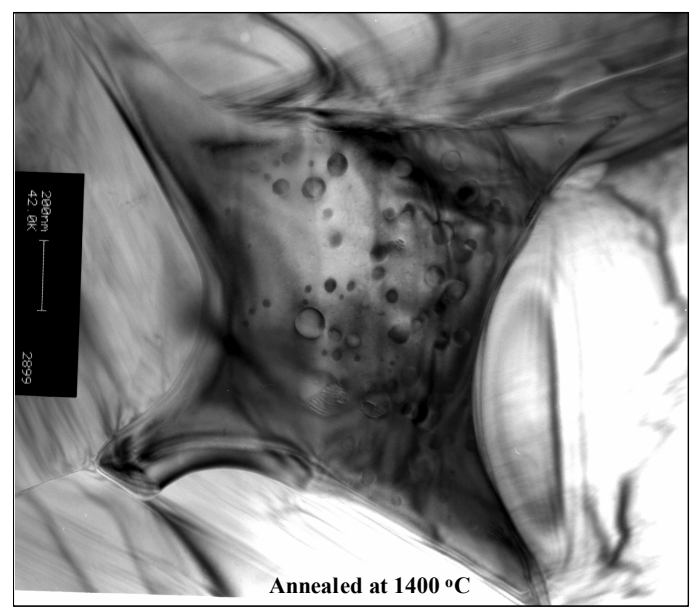

Fig. 6: A secondary-phase particle in the $1400^{\circ} \mathrm{C}$-annealed sample. Note the second phase separation within the particle.

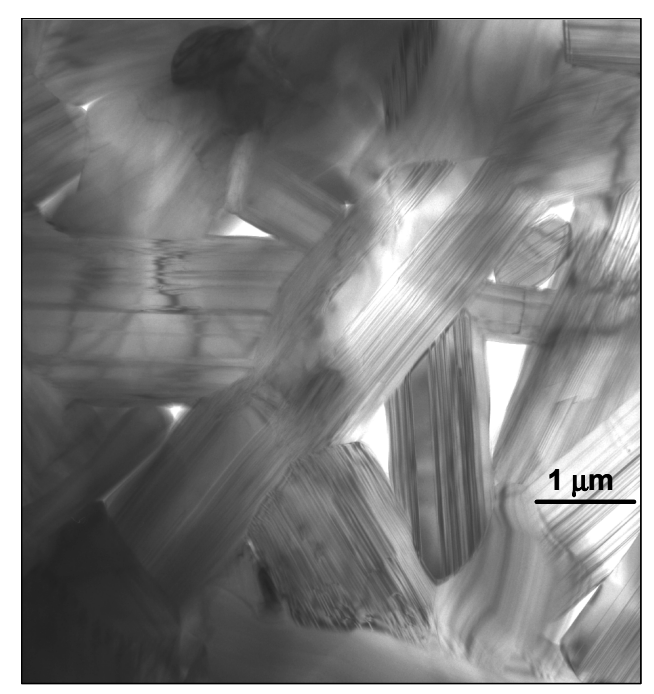

Fig. 7: Empty triple-pockets observed in $\mathrm{ABC}-\mathrm{SiC}$ samples after the thermal treatment at $1600^{\circ} \mathrm{C}$. Note the $100 \%$ occupied triple-pockets in as-hot-pressed samples, Fig. 1.

Summarizing the TEM results for the annealing temperatures between 800 and $1600^{\circ} \mathrm{C}$, we have found that grain boundary diffusion became significant at about $1000^{\circ} \mathrm{C}$, resulting in amorphous-to-crystalline transformation in IGFs. The lattice diffusion in $\mathrm{SiC}$ became significant at about $1300^{\circ} \mathrm{C}$, as evidenced by the appearance of the nanoprecipitates and precipitate-depletion zones in the vicinity of grain boundaries. Heating at $1600^{\circ} \mathrm{C}$ had remarkable influences on secondary phase particles. 
Thermal treatment at $1900^{\circ} \mathrm{C}$

Crystallization of IGFs can be expected to affect mechanical properties such as high temperature creep. $^{24}$ The stability of the crystallized grain boundary films at high temperatures is therefore of interests. As a test, an as-hot-pressed ABC-SiC sample was first annealed in argon, at $1500^{\circ} \mathrm{C}$, for $168 \mathrm{hrs}$, to crystallize the IGFs. After cooling, a slice of this sample was further subjected to heating at $1900^{\circ} \mathrm{C}$, for $5 \mathrm{~min}$, in the same environment. Fig. 8 compares high-resolution images of IGFs in the as-hot-pressed, the $1500^{\circ} \mathrm{C}$-annealed, and the $1900^{\circ} \mathrm{C}$-treated samples. As expected, the amorphous IGF in the as-hot-pressed sample (Fig. 8a) was crystallized at $1500^{\circ} \mathrm{C}$ (Fig. 8b). After subsequent firing at $1900^{\circ} \mathrm{C}$, high-resolution electron microscopy showed an amorphous structure (Fig. 9c) for $\sim 39 \%$ out of 23 IGFs examined, while another $61 \%$ were crystalline IGFs (Fig. 9d). These percentages significantly differed from that in the as-hot-pressed and $1500^{\circ} \mathrm{C}$ annealed samples. For example, $86 \%$ IGFs examined in the $1500^{\circ} \mathrm{C}$-annealed $\mathrm{SiC}$ were crystalline, while about the same fraction of IGFs were amorphous in the as-hot-pressed samples. The 39:61 ratio obtained in the $1900^{\circ} \mathrm{C}$-treated samples suggested that the treatment at $1900^{\circ} \mathrm{C}$ re-melted $\sim 25 \%$ of the crystallized IGFs. It was also noticed that the mean value for the width of the disordered IGFs was reduced by about $44 \%$ with respect to that of the as-hot-pressed samples.
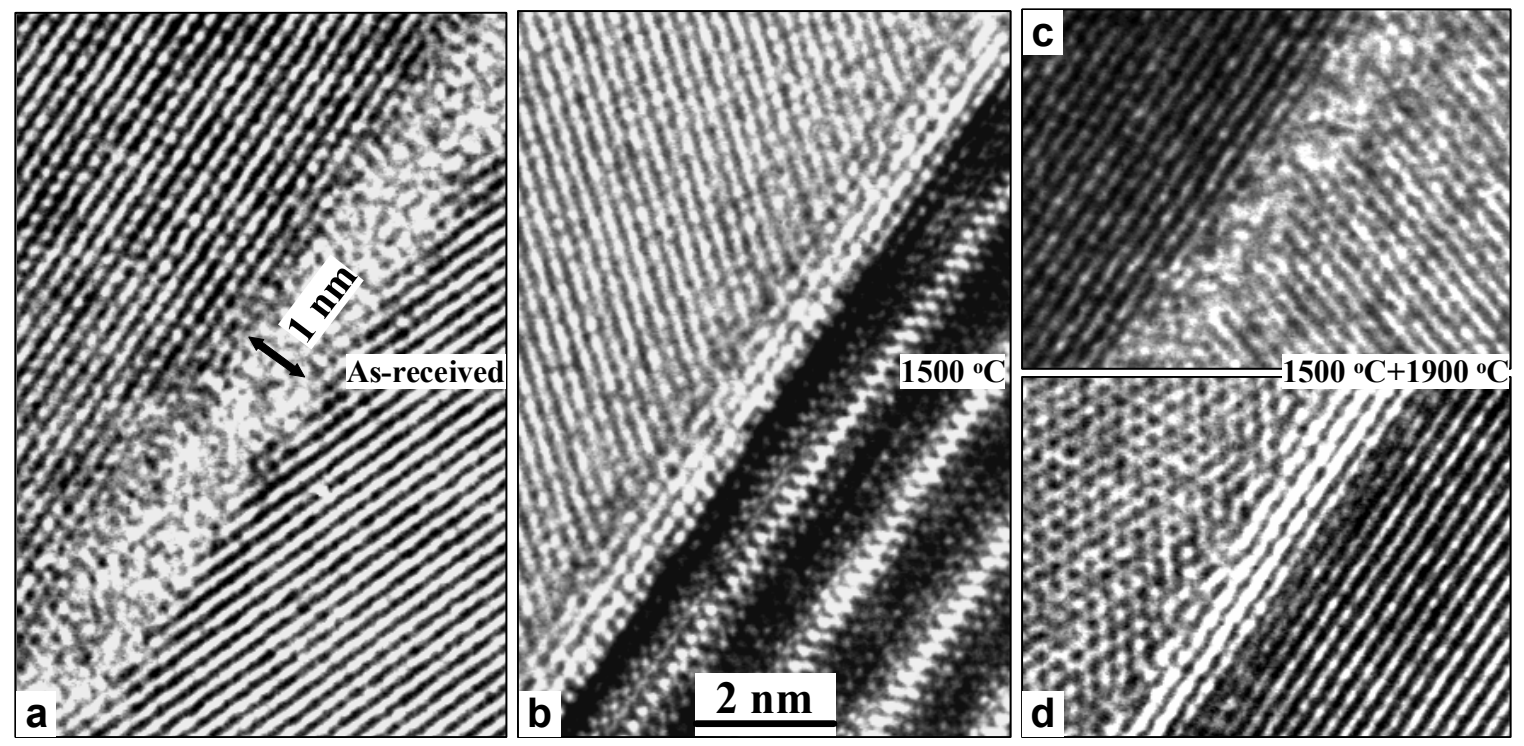

Fig. 8: High-resolution micrographs obtained from (a), the as-hot-pressed sample, (b), the $1500^{\circ} \mathrm{C}$-annealed sample, (c) and (d), the $1900^{\circ} \mathrm{C}$-treated sample. The $1500^{\circ} \mathrm{C}$ treatment crystallized the amorphous IGF, while the subsequent brief holding at $1900^{\circ} \mathrm{C}$ re-melted some crystalline IGFs. Note that the images were not taken from the same IGF. 
EDS spectra showed the same elemental constituents in IGFs in the $1500^{\circ} \mathrm{C}$ - and the $1900^{\circ} \mathrm{C}$-treated samples. Particularly, Al and O peaks were readily detectable in both samples. Detailed EDS quantification was performed to determine the Al concentration in $\mathrm{SiC}$ grains $(\mathrm{Al} / \mathrm{SiC} \mathrm{wt} \%)$, the $\mathrm{Al}$ excess in grain boundary films $\left(\Gamma_{\mathrm{Al}}\right.$, defined as $\mathrm{Al}$ atom excess per grain boundary area with respect to that in $\mathrm{SiC}$ ), as well as the $\mathrm{C} / \mathrm{Si}$ atom ratio in $\mathrm{SiC}$ grains. The results are summarized in Table I. It can be seen that $\Gamma_{\mathrm{Al}}$ values obtained from the $1500^{\circ} \mathrm{C}$ - and the $1900^{\circ} \mathrm{C}$-treated samples are close, indicating the existence of the Al-rich IGFs even after the $1900^{\circ} \mathrm{C}$ treatment, therefore confirming the high-resolution observation of the IGFs in Fig. 8. C/Si atom ratios in both samples are close to the unity; therefore, no stoichiometry changes $\mathrm{SiC}$ develop as a result of this treatment.

Table I: EDS-determined $\mathrm{Al}$ concentration in $\mathrm{SiC}$ grains $(\mathrm{Al} / \mathrm{SiC}$ wt $\%), \mathrm{Al}$ excess in grain boundary films $\left(\Gamma_{\mathrm{Al}}\right)$, as well as $\mathrm{C} / \mathrm{Si}$ atom ratio in samples annealed at $1500^{\circ} \mathrm{C}$ and the same bulk piece subsequently fired at $1900^{\circ} \mathrm{C}$. Statistical mean values are listed with standard deviations.

\begin{tabular}{llll}
\hline $\begin{array}{l}\text { Samples } \\
\mathrm{ABC}-\mathrm{SiC}\end{array}$ & $\begin{array}{l}\mathrm{Al} / \mathrm{SiC} \\
(\mathrm{wt} \%)\end{array}$ & $\begin{array}{l}\Gamma_{\mathrm{Al}} \\
\left(\mathrm{nm}^{-2}\right)\end{array}$ & $\begin{array}{l}\text { C/Si } \\
(\text { atom ratio })\end{array}$ \\
\hline $1500^{\circ} \mathrm{C}-168 \mathrm{hrs}$ & $1.6 \pm 0.2$ & $19.7 \pm 9.5$ & $1.23 \pm 0.20^{\#}$ \\
$1900^{\circ} \mathrm{C}-5 \mathrm{~min}$. & $1.4 \pm 0.1$ & $16.4 \pm 4.5$ & $0.94 \pm 0.36$ \\
\hline
\end{tabular}

\#Hydrocarbon contamination during EDS spectrum acquisition caused a greater $\mathrm{C} / \mathrm{Si}$ mean value.

Selected-area electron diffraction was performed on $\mathrm{SiC}$ grains to detect possible change in lattice parameters caused by the $1900^{\circ} \mathrm{C}$ heating. The diffraction analyses were concentrated on $\alpha-4 \mathrm{H}$ and $\alpha-6 \mathrm{H}$ major phases in ABC-SiC. The results are given in Table II. It can be seen that in comparison with the as-hot-pressed $\mathrm{ABC}-\mathrm{SiC}$, annealing at $1500^{\circ} \mathrm{C}$ resulted in virtually no changes in lattice parameters within the experimental errors. However, exposure to $1900^{\circ} \mathrm{C}$ for $5 \mathrm{~min}$. substantially dilated the hexagonal unit cells. The unit cells of $4 \mathrm{H}$ and $6 \mathrm{H}$ phases expanded by $12.4 \pm 9.9 \%$, and $5.2 \pm 4.5 \%$, respectively. Curiously, the unit cells in $4 \mathrm{H}$ and $6 \mathrm{H}$ phases dilated along the different directions. The $4 \mathrm{H}$ phase expanded mainly in the hexagonal basal planes, whereas the $6 \mathrm{H}$ phase expanded 
mostly along the $c$-direction. The fact that the unit cell dilation was observed at room temperature indicates that the expansion of the unit cell at $1900^{\circ} \mathrm{C}$ in $\operatorname{argon}$ was irreversible on cooling.

Table II: Lattice parameters determined using selected-area electron diffraction. 4H- and 6H-SiC grains were analyzed. Experimental errors are adopted. Volume dilation for the unit cells after annealing is calculated with respect to the as-hot-pressed samples.

\begin{tabular}{|c|c|c|}
\hline ABC-SiC & $\alpha-4 H\left(\mathbf{P 6}_{3} \mathrm{mc}\right)$ & $\alpha-6 H\left(\mathrm{P6}_{3} \mathrm{mc}\right)$ \\
\hline $\begin{array}{c}\text { As-Hot-Pressed } \\
\text { a }(\AA) \\
\text { c }(\AA)\end{array}$ & $\begin{array}{l}3.07 \pm 0.03 \\
10.03 \pm 0.21\end{array}$ & $\begin{array}{l}3.06 \pm 0.03 \\
14.89 \pm 0.38\end{array}$ \\
\hline $\begin{array}{c}1500^{\circ} \mathrm{C}-168 \mathrm{hrs} \\
\mathrm{a}(\AA) \\
\mathrm{c}(\AA)\end{array}$ & $\begin{array}{l}3.08 \pm 0.03 \\
9.99 \pm 0.21\end{array}$ & $\begin{array}{l}3.08 \pm 0.03 \\
15.02 \pm 0.24\end{array}$ \\
\hline Volume Dilation & Negligible & Negligible \\
\hline $\begin{array}{c}1900^{\circ} \mathrm{C}-5 \min ^{\#} \\
\mathrm{a}(\AA) \\
\mathrm{c}(\AA)\end{array}$ & $\begin{array}{l}3.19 \pm 0.04 \\
10.44 \pm 0.23\end{array}$ & $\begin{array}{l}3.06 \pm 0.03 \\
15.66 \pm 0.26\end{array}$ \\
\hline Volume Dilation & $12.4 \pm 9.9 \%$ & $5.2 \pm 4.5 \%$ \\
\hline
\end{tabular}

\#From the same bulk sample first annealed at $1500^{\circ} \mathrm{C}$ for $168 \mathrm{hrs}$ and cooled.

In addition to change of the IGF structure and unit cell dilation in the ABC-SiC after the $1900^{\circ} \mathrm{C}$ thermal treatment, dissolution of the nanoprecipitates that formed at lower temperatures, and evaporation of second-phase particles were also observed. The dissolved nanoprecipitates did not diffuse into SiC lattice. Some of these changes such as unit cell dilation could cause stress and cracking. The micrograph in Fig. 9 shows cracks in the sample after the $1900^{\circ} \mathrm{C}$ thermal treatment. It should be emphasized that some microstructural changes observed in the $1900^{\circ} \mathrm{C}$-treated sample could be surface-related because the corresponding TEM sample was sectioned from a within $100 \mu \mathrm{m}$ depth from the bulk surface. 


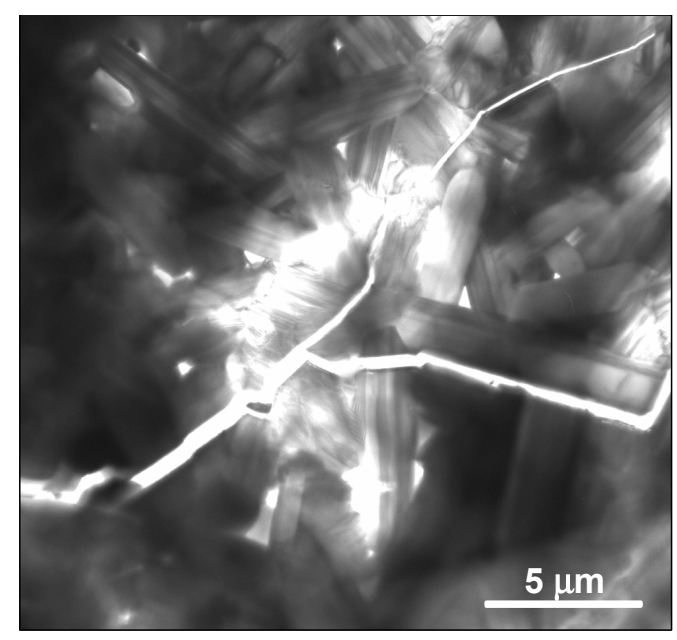

Fig. 9: Cracks in the sample after holding at $1900^{\circ} \mathrm{C}$ for $5 \mathrm{~min}$.

\section{DISCUSSION}

In the above section, we have demonstrated that the amorphous $\mathrm{Al}-\mathrm{O}-\mathrm{Si}-\mathrm{C}$ IGFs in $\mathrm{ABC}-\mathrm{SiC}$ started to crystallize at $\sim 1000^{\circ} \mathrm{C}$, and fully crystallized above $1100^{\circ} \mathrm{C}$. These results agreed well with the experimental work by Rouxel et al, in which partial crystallization was observed in the bulk SiOC glasses at $>1150^{\circ} \mathrm{C}$, and the crystallization was more completed at $1300^{\circ} \mathrm{C}^{31}$ The similar amorphous-to-crystalline transitions in the two systems may be attributed to the similar elemental constituents. Indeed, the crystallization temperature $\left(\sim 1000^{\circ} \mathrm{C}\right)$ of the amorphous IGFs studied in the present work is lower than that of the bulk $\mathrm{SiOC}$ glasses, presumably because of the presence of $\mathrm{Al}$ and the close to two-dimensional geometry of the IGFs. Another fact worthy of note is the high stability of the crystallized IGF structure: about $60 \%$ crystallized IGFs survived the shorttime $1900^{\circ} \mathrm{C}$ treatment. Considering that one of the IGF structures was determined to be $\mathrm{Al}_{2} \mathrm{OC}$-like with $\mathrm{SiC}$ solid solution, ${ }^{11}$ the stable IGF structure at high temperature would not be in agreement with the conclusion by Lihrmann et al. that $\mathrm{Al}_{2} \mathrm{OC}$ structure tended to decompose at $>1200^{\circ} \mathrm{C}$, following a chemical reaction of $4 \mathrm{Al}_{2} \mathrm{OC} \rightarrow \mathrm{Al}_{4} \mathrm{O}_{4} \mathrm{C}+\mathrm{Al}_{4} \mathrm{C}_{3}{ }^{32}$ It is possible that the observed transport of $\mathrm{Al}-\mathrm{C}$ from nanoprecipitates into the IGFs at temperature above $1200^{\circ} \mathrm{C}$ impeded the decomposition reaction in $\mathrm{ABC}-\mathrm{SiC}$.

Nagano et al. reported that $\mathrm{SiC}$ sintered with $\mathrm{Al}$ additives lost weight at $1800^{\circ} \mathrm{C}$ in argon atmosphere, and attributed the weight loss to vaporization of the grain boundary 
phase, the decomposition of $\mathrm{SiC}$, as well as eroded surface. ${ }^{26}$ Our experiments confirmed minor dissolution of $\mathrm{SiC}$ grains and somewhat reduction in the amount of grain boundary material (narrower IGFs) at $1900^{\circ} \mathrm{C}$ in the near-to-surface areas. However, a large number of empty triple-junction pockets are more likely to cause the noticeable weight loss. What remained to be mysterious is that those thermal effects seen in samples after the $1900^{\circ} \mathrm{C}$ treatment did not present in the as-processed samples which after all were hot-pressed at $1900^{\circ} \mathrm{C}$. Much of the effects would therefore be related to the near-to-surface features or have to be associated with evaporative processes that are suppressed in the closed die used in hot pressing.

\section{CONCLUSIONS}

Systematic TEM characterization has been performed on hot-pressed ABC-SiC samples annealed between $800^{\circ} \mathrm{C}$ and $1600^{\circ} \mathrm{C}$, and at $1900^{\circ} \mathrm{C}$. It was found that thermal treatment above $1000^{\circ} \mathrm{C}$ crystallized the amorphous intergranular films. At about $1300^{\circ} \mathrm{C}$, Al diffusion in $\mathrm{SiC}$ lattice became significant, resulting in the formation of uniformly dispersed, nanoscale precipitates inside $\mathrm{SiC}$ grains. The lattice diffusion led to enrichment of the $\mathrm{Al}$ content in the IGFs.

At $1600^{\circ} \mathrm{C}$, evidence of volatilization could be found in triple junction pore formation due to evaporation of secondary phase particles. The IGFs survived the $5 \mathrm{~min}$ treatment at $1900^{\circ} \mathrm{C}$, but at least $25 \%$ of the IGFs re-melted, with no significant changes in chemical constituents compared to that in $1500^{\circ} \mathrm{C}$-annealed samples. Other structural responses to the $1900^{\circ} \mathrm{C}$-heating include dissolution of the nanoprecipitates, evaporation of secondary-phase particles, unit cell dilation, as well as extensive cracking in near freesurface regions. It can be concluded that $\mathrm{ABC}-\mathrm{SiC}$ is a good candidate material for structural application at up to $1500^{\circ} \mathrm{C}$. 


\section{ACKNOWLEDGMENT:}

This work was supported by the Director, Office of Science, Office of Basic Energy Sciences, Division of Materials Sciences and Engineering of the U.S. Department of Energy under Contract No. DE-AC03-76SF0098. Part of this work was made possible through the use of the National Center for Electron Microscopy facility at the Lawrence

Berkeley National Laboratory. Thanks are due to Qing Yang for her help in processing the SiC samples. 


\section{REFERENCES}

1. T. Mitchell, Jr., L.C. Dejonghe, W.J. MoberlyChan, and R.O. Ritchie, J. Am. Ceram. Soc. 78, 97 (1995).

2. P.F. Becher, J. Am. Ceram. Soc. 74, 255 (1991).

3. P.F. Becher, E.Y. Sun, K.P. Plucknett, K.B. Alexander, C.H. Hsueh, H.T. Lin, S.B. Waters, and C.G. Westmoreland, J. Am. Ceram. Soc. 81, 2821 (1998).

4. J.J. Cao, W.J. MoberlyChan, L.C. De Jonghe, C.J. Gilbert, and R.O. Ritchie, J. Am. Ceram. Soc. 79, 461 (1996).

5. N. P. Padture, "In Situ-Toughened Silicon Carbide," J. Am. Ceram. Soc. 77, 519 (1994).

6. F.F. Lange, J. Mater. Sci. 10, 314 (1975).

7. R. Hamminger, G. Grathwohl, and F. Thummler, J. Mater. Sci. 18, 353 (1983).

8. L. Sigl, and H.-J. Kleebe, J. Am. Ceram. Soc. 76, 773 (1993).

9. W.J. MoberlyChan, J.J. Cao, and L.C. De Jonghe, Acta Mater. 46, 1625 (1998).

10. W.J. MoberlyChan, and L.C. De Jonghe, Acta Mater. 46, 2471 (1998).

11. X.F. Zhang, M.E. Sixta, and L.C. De Jonghe, J. Am. Ceram. Soc. 83, 2813 (2000).

12. J.-L. Huang, A.C. Hurford, R.A. Cutler, and A.V. Virkar, J. Mater. Sci. Lett. 21, 1448 (1986).

13. A.K. Misra, J. Am. Ceram. Soc. 74, 345 (1991).

14. C.J. Gilbert, J.J. Cao, L.C. De Jonghe, and R.O. Ritchie, J. Am. Ceram. Soc. 80, 2253 (1997).

15. K.T. Faber, and A.G. Evans, Acta Metall. 31, 565 (1983).

16. K.T. Faber, and A.G. Evans, Acta Metall. 31, 577 (1983).

17. P.F. Becher, C.H. Hsueh, P. Angelini, and T.N. Tiegs, J. Am. Ceram. Soc. 71, 1050 (1988).

18. D. Chen, C.J. Gilbert, X.F. Zhang, and R.O. Ritchie, Acta Mater. 48, 659 (2000).

19. D. Chen, X.F. Zhang, and R.O. Ritchie, J. Am. Ceram. Soc. 83, 2079 (2000).

20. D. Chen, M.E. Sixta, X.F. Zhang, L.C. De Jonghe, and R.O. Ritchie, Acta Mater. 48, 4599 (2000). 
21. X.F. Zhang, M.E. Sixta, and L.C. De Jonghe, J. Mater. Sci. 36, 5447 (2001).

22. R.O. Ritchie, D. Chen, and X.F. Zhang, Int. J. Mater. Prod. Tech. 1, 331 (2001).

23. X.F. Zhang, M.E. Sixta, and L.C. De Jonghe, Defect and Diffusion Forum 186-187, 45 (2000).

24. M.E. Sixta, X.F. Zhang, and L.C. De Jonghe, J. Am. Ceram. Soc. 84, 2022 (2001).

25. X.F. Zhang, G.Y. Lee, D. Chen, R.O. Ritchie, and L.C. De Jonghe, J. Am. Ceram. Soc. in press.

26. T. Nagano, K. Kaneko, G.-D. Zhan, and M. Mitomo, J. Am. Ceram. Soc. 83, 2781 (2000).

27. X.F. Zhang, Q. Yang, L.C. De Jonghe, and Z. Zhang, J. Microsc. 207, 58 (2002).

28. H. Ribes, M. Suery, G. L'Esperance, and J.G. Legoux, Metall. Trans. 21A, 2489 (1990).

29. X.F. Zhang, M.E. Sixta, and L.C. De Jonghe, J. Am. Ceram. Soc. 84, 813 (2001).

30. I.B. Cutler, P.D. Miller, W. Rafaniello, H.K. Park, D.P. Thompson, and K.H. Jack, Nature 275, 434 (1978).

31. T. Rouxel, G-.D. Soraru, and J. Vicens, J. Am. Ceram. Soc. 84, 1052 (2001).

32. J.M. Lihrmann, T. Zambetakis, and M. Daire, J. Am. Ceram. Soc. 72, 1704 (1989). 
Table I: EDS-determined $\mathrm{Al}$ concentration in $\mathrm{SiC}$ grains ( $\mathrm{Al} / \mathrm{SiC}$ wt $\%), \mathrm{Al}$ excess in grain boundary films $\left(\Gamma_{\mathrm{Al}}\right)$, as well as $\mathrm{C} / \mathrm{Si}$ atom ratio in samples annealed at $1500^{\circ} \mathrm{C}$ and the same bulk piece subsequently fired at $1900^{\circ} \mathrm{C}$. Statistical mean values are listed with standard deviations.

\begin{tabular}{llll}
\hline $\begin{array}{l}\text { Samples } \\
\mathrm{ABC}-\mathrm{SiC}\end{array}$ & $\begin{array}{l}\mathrm{Al} / \mathrm{SiC} \\
(\mathrm{wt} \%)\end{array}$ & $\begin{array}{l}\Gamma_{\mathrm{Al}} \\
\left(\mathrm{nm}^{-2}\right)\end{array}$ & $\begin{array}{l}\mathbf{C} / \mathrm{Si} \\
(\text { atom ratio })\end{array}$ \\
\hline $1500^{\circ} \mathrm{C}-168 \mathrm{hrs}$ & $1.6 \pm 0.2$ & $19.7 \pm 9.5$ & $1.23 \pm 0.20^{\#}$ \\
$1900^{\circ} \mathrm{C}-5 \mathrm{~min}$. & $1.4 \pm 0.1$ & $16.4 \pm 4.5$ & $0.94 \pm 0.36$ \\
\hline
\end{tabular}

\#Hydrocarbon contamination during EDS spectrum acquisition caused a greater C/Si mean value.

Table II: Lattice parameters determined using selected-area electron diffraction. $4 \mathrm{H}-$ and $6 \mathrm{H}-\mathrm{SiC}$ grains were analyzed. Experimental errors are adopted. Volume dilation for the unit cells after annealing is calculated with respect to the as-hot-pressed samples.

\begin{tabular}{|c|c|c|}
\hline ABC-SiC & $\alpha-4 H\left(\mathrm{~Pb}_{3} \mathrm{mc}\right)$ & $\alpha-6 H\left(P 6_{3} \mathrm{mc}\right)$ \\
\hline $\begin{array}{c}\text { As-Hot-Pressed } \\
\text { a }(\AA) \\
\text { c }(\AA)\end{array}$ & $\begin{array}{l}3.07 \pm 0.03 \\
10.03 \pm 0.21\end{array}$ & $\begin{array}{l}3.06 \pm 0.03 \\
14.89 \pm 0.38\end{array}$ \\
\hline $\begin{array}{c}1500^{\circ} \mathrm{C}-168 \mathrm{hrs} \\
\mathrm{a}(\AA) \\
\mathrm{c}(\AA)\end{array}$ & $\begin{array}{l}3.08 \pm 0.03 \\
9.99 \pm 0.21\end{array}$ & $\begin{array}{l}3.08 \pm 0.03 \\
15.02 \pm 0.24\end{array}$ \\
\hline Volume Dilation & Negligible & Negligible \\
\hline $\begin{array}{c}1900^{\circ} \mathrm{C}-5 \min ^{\#} \\
\mathrm{a}(\AA) \\
\mathrm{c}(\AA)\end{array}$ & $\begin{array}{l}3.19 \pm 0.04 \\
10.44 \pm 0.23\end{array}$ & $\begin{array}{l}3.06 \pm 0.03 \\
15.66 \pm 0.26\end{array}$ \\
\hline Volume Dilation & $12.4 \pm 9.9 \%$ & $5.2 \pm 4.5 \%$ \\
\hline
\end{tabular}

\#From the same bulk sample first annealed at $1500^{\circ} \mathrm{C}$ for $168 \mathrm{hrs}$ and cooled. 


\section{Figure captions:}

Fig. 1: General microstructural morphology of as-hot-pressed ABC-SiC.

Fig. 2: Three high-resolution images taken from an $\mathrm{ABC}-\mathrm{SiC}$ sample annealed at $1000^{\circ} \mathrm{C}$ for 5 hrs. IGFs with (a) amorphous, (b) partially ordered, and (c) crystallized structures can be seen.

Fig. 3: (a), High-resolution image of an amorphous IGF in as-hot-pressed ABC-SiC. (b), The same IGF as in (a) but after in-situ heating in a transmission electron microscope at $1200^{\circ} \mathrm{C}$ for $25 \mathrm{hrs}$. Arrows indicate the discrete, crystallized IGF segments. The highresolution image in (b) was taken at room temperature.

Fig. 4: Nanoprecipitates formed in an $\mathrm{ABC}-\mathrm{SiC}$ sample annealed at $1400^{\circ} \mathrm{C}$. Precipitatedepletion zone along the grain boundary can be seen.

Fig. 5: Plots of EDS-determined Al site density in grain boundary films $\left(\mathrm{N}_{\mathrm{Al}}{ }^{\mathrm{GB}}\right)$ and in $\mathrm{SiC}$ matrix grains $(\mathrm{Al} / \mathrm{SiC}, \mathrm{wt} \%)$ as a function of annealing temperature. Standard deviations are given.

Fig. 6: A secondary-phase particle in the $1400^{\circ} \mathrm{C}$-annealed sample. Note the second phase separation within the particle.

Fig. 7: Empty triple-pockets observed in ABC-SiC samples after the thermal treatment at $1600^{\circ} \mathrm{C}$. Note the $100 \%$ occupied triple-pockets in as-hot-pressed samples, Fig. 1.

Fig. 8: High-resolution micrographs obtained from (a), the as-hot-pressed sample, (b), the $1500^{\circ} \mathrm{C}$-annealed sample, (c) and (d), the $1900^{\circ} \mathrm{C}$-treated sample. The $1500^{\circ} \mathrm{C}$ treatment crystallized the amorphous IGF, while the subsequent brief holding at $1900^{\circ} \mathrm{C}$ re-melted some crystalline IGFs. Note that the images were not taken from the same IGF.

Fig. 9: Cracks in the sample after holding at $1900^{\circ} \mathrm{C}$ for $5 \mathrm{~min}$. 